\title{
Divulgação Científica: a última e imprescindível etapa do processo científico
}

A etapa de comunicação dos resultados de uma investigação, também chamado de divulgação científica, culmina o processo científico. $\mathrm{O}$ fato de incluir a pesquisa e o pesquisador na cena e no debate nacional e internacional torna essa atividade imprescindível. A forma contemporânea predominante de comunicação científica são os artigos, tendo como meio as revistas, as quais, por sua vez, compõem bases de dados nacionais, regionais e internacionais.

A produção de uma revista constitui um empreendimento composto por complexas atividades e envolvimento de muitos atores. No caso de Ciência \& Saúde Coletiva, para cada artigo publicado - com sua personalidade e sua história própria - mais de $2 / 3$ retornam a seus autores porque não tiveram mérito ou não corresponderam ao escopo do veículo. Uma boa quantidade, porém, é devolvida para aprimoramento de conteúdo e de forma, e todo o empenho dos editores se orienta para veicular os temas e os nomes dos pesquisadores mais produtivos e relevantes.

Nenhuma revista consegue a perfeição. Mas existe um consenso irretocável na comunidade científica sobre a necessidade de compartilhar a ciência que é construída nos laboratórios e em grupos de pesquisa, levando a uma conclusão radical de que ciência não-comunicada é ciência que não existe: ninguém pode adivinhar o que se passa na sala de um pesquisador se sua atividade investigativa não vem a público por meio de um formato consagrado internacionalmente. Lafuente e colaboradores chegam a inverter a tese cartesiana segundo a qual penso, logo existo dizendo que no mundo científico: existo porque sou pensado e não porque penso.

Cuidar de uma revista é um trabalho de "formiguinha" que fascina pelos desafios que encerra. Construir, manter e aprimorar um periódico científico exige dedicação cotidiana que vai do aprimoramento dos procedimentos até a visão de estratégias para evitar seu desaparecimento ou irrelevância e garantir seu lugar entre as melhores. Além do trabalho interno, o emprendedorismo nesse campo significa ultrapassar a sala da editoria e ganhar os fóruns da política de Ciência \& Tecnologia. O editor tem que estar engajado tanto na busca do reconhecimento nacional como na internacionalização de seu periódico. Internamente, porque a ciência tem que dar resposta a questões nacionais. Externamente, porque a ciência assim como o capital (parafraseando Marx) não tem pátria. Sua linguagem universal e seus procedimentos padronizados e regulados universalmente unem os quatro cantos do mundo.

Ciência \& Saúde Coletiva cumpre o papel de viabilizar aos pesquisadores e gestores da área o compartilhamento de seu conhecimento, dando-lhe dimensão universal. Para que tenham idéia do tamanho dessa tarefa, eis alguns dados de produtividade da Revista em 2011: 1830 artigos recebidos através do site; 507 publicados; 127 aprovados e ainda não publicados; 1359 recusados; 149 sob condição aguardando parecer final e 224 em processo de avaliação. Ela está indexada em 17 bases nacionais e internaconais e, neste ano de 2011, foi incluída no Journal Citation Reports (JCR), um recurso que permite avaliar e comparar os periódicos internacionalmente mais citados em determinada área e a relevância da publicação para a comunidade científica, por meio do fator de impacto. Isso significa que progressivamente nossa Revista vai atingindo mais importância e ganhando padrões internacionais.

Possuímos um plano de progressiva internacionalização, de aumento de parcerias e de ampliação e aprofundamento de sua divulgação. O respeito e o carinho dos autores e leitores, as sábias orientações do corpo de editores e conselheiros, a dedicação incomensurável de seu grupo executivo, o apoio das sucessivas diretorias da Abrasco já lhe garantiram um lugar imprescindível no campo das idéias sobre saúde.

Maria Cecília de Souza Minayo

Romeu Gomes

Editores chefes 